\title{
Progesterone stimulates pancreatic cell proliferation in vivo
}

\author{
A G Nieuwenhuizen, G A Schuiling, S M S Liem, H Moes, T R Koiter and J Th J Uilenbroek ${ }^{1}$ \\ Division of Reproductive Biology, Department of Obstetrics and Gynaecology, University of Groningen, Hanzeplein 1, NL-9713 GZ Groningen, \\ The Netherlands and ${ }^{1}$ Department of Endocrinology and Reproduction, Erasmus University, Rotterdam, The Netherlands \\ (Correspondence should be addressed to A Nieuwenhuizen)
}

\begin{abstract}
Treatment of cyclic and pregnant rats with progesterone stimulates cell proliferation within the islets of Langerhans. It was investigated whether this effect of progesterone depends on sex and/or the presence of the gonads or the presence of oestradiol. For this purpose, Silastic tubes containing progesterone were inserted s.c. in intact and gonadectomized male and female rats, and in gonadectomized female rats treated with oestradiol. After 6 days of progesterone treatment, rats were infused for $24 \mathrm{~h}$ with 5bromo-2'-deoxyuridine (BrdU) and dividing cells were identified in pancreatic sections by immunostaining for BrdU. Progesterone treatment increased islet-cell proliferation in intact male and female rats $(P<0.05)$, but not in gonadectomized male and female rats or in gonadectomized female rats supplemented with oestradiol. Furthermore, in intact male and female rats, progesterone treatment also stimulated cell proliferation in extra-islet pancreatic tissue $(P<0.05)$. Identification of the proliferating cells, by double-immunocytochemistry, revealed that progesterone treatment stimulated proliferation of both $\alpha$ and $\beta$ cells within the pancreatic islets. In extra-islet pancreatic tissue, progesterone treatment stimulated proliferation in both duct (cytokeratin 20-immunoreactive) and non-duct cells. Progesterone treatment did not increase the number of single glucagon or insulincontaining cells outside the pancreatic islets, nor that of cytokeratin 20/insulin double-positive cells, suggesting that progesterone treatment did not stimulate differentiation of duct cells into endocrine cells. Progesterone treatment did not affect insulin responses to an i.v. glucose load $(0.5 \mathrm{~g} / \mathrm{kg}$ body weight). It is concluded that progesterone stimulates pancreatic cell proliferation indirectly; gonadal factor(s), not identical to oestradiol, is (are) probably involved.
\end{abstract}

European Journal of Endocrinology 140 256-263

\section{Introduction}

Treatment of cyclic female rats with progesterone increases plasma concentrations of progesterone and stimulates islet-cell proliferation, but does not affect glucose-stimulated insulin secretion in vivo (1). A stimulatory effect of progesterone treatment on pancreatic islet-cell proliferation was also observed in day-14 pregnant rats, but in these animals progesterone treatment did not result in increased plasma levels of progesterone, as these animals are able to maintain the plasma progesterone concentrations at the physiological level (1). Hence, it was suggested that the proliferative effect of progesterone treatment on the pancreatic islets might be indirect rather than direct (1).

A direct effect of progesterone on the islets of Langerhans may be possible in intact female rats, as both the pancreatic $\alpha$ and $\beta$ cells of these animals possess progesterone receptors $(2,3)$. Yet, a direct effect of progesterone on islet-cell proliferation is less likely in ovariectomized (OVX) rats, as ovariectomy causes loss of the progesterone receptors within the pancreatic islets; this loss can be prevented by oestradiol (E2) substitution (3). In male rats, a direct effect of progesterone seems unlikely as well, as the pancreas of male rats does not contain significant levels of progesterone receptors (4). The question whether the effect of progesterone on isletcell proliferation may be direct or indirect was therefore investigated using both intact and gonadectomized male (TX) and OVX female rats, and also in E2-treated OVX rats. Islet-cell proliferation was assessed by the 5-bromo-2'-deoxyuridine (BrdU) method (5); the effects of progesterone treatment on extra-islet pancreatic tissue were studied as well. Proliferating cells were identified by immunostaining for either insulin, glucagon, synaptophysin (expressed selectively in neuroendocrine cells (6)) or the immunocytochemical marker of ductular epithelium, cytokeratin 20 (7). Finally, the effects of progesterone treatment on pancreatic islet function were investigated by i.v. glucose tolerance tests (IVGTTs).

\section{Materials and methods}

\section{Animals}

Male and female Wistar rats were used, aged 3-4 months and weighing $180-220 \mathrm{~g}$. They were housed at $22 \pm 1{ }^{\circ} \mathrm{C}$, with lights on from $0630 \mathrm{~h}$ until $1730 \mathrm{~h}$, and 
with water and food (Code 1062, Hope Farms, Woerden, The Netherlands) freely available.

To allow frequent stress-free sampling of blood from freely moving rats, a silicone cannula (internal diameter (ID) $0.5 \mathrm{~mm}$, outside diameter (OD) $1.0 \mathrm{~mm}$ ) was introduced via the right jugular vein under light ether anaesthesia, according to the method described by Steffens (8). On the same day, some of the animals' ovaries/testes were removed under light ether anaesthesia; other rats were sham-operated. One group of OVX rats was continuously supplemented with E2 from 9 days after removal of the ovaries. Two Silastic implants (Dow Corning, Midland, MI, USA; length $1.5 \mathrm{~cm}$, ID $1.47 \mathrm{~mm}$, OD $1.96 \mathrm{~mm})$ containing $\beta$ oestradiol (Sigma Chemical Co., St Louis, MO, USA) were implanted s.c. under light ether anaesthesia. This treatment establishes plasma E2 concentrations which are within the physiological range (9).

\section{Progesterone treatment}

Fourteen days after implantation of the cannula and gonadectomy, progesterone was administered continuously for 7 days by means of three Silastic tubes (length $3.8 \mathrm{~cm}$, ID $3.35 \mathrm{~mm}$, OD $4.64 \mathrm{~mm}$ ) containing crystallized progesterone which were implanted s.c. under light ether anaesthesia. Control animals received three identical but empty implants. This resulted in ten experimental groups: control intact female rats $(n=7)$, progesterone-treated intact female rats $(n=7)$, control OVX rats $(n=5)$, progesterone-treated OVX rats $(n=5)$, control OVX rats treated with E2 $(n=5)$, progesteronetreated OVX rats treated with E2 $(n=7)$, control intact male rats $(n=5)$, progesterone-treated intact male rats $(n=5)$, control TX rats $(n=5)$ and progesterone-treated TX rats $(n=6)$. After 6 days of continuous progesterone treatment IVGTTs were carried out as described previously (10). In short: at $1100 \mathrm{~h}$ the rats received a glucose injection $(0.5 \mathrm{~g} / \mathrm{kg}$ body weight, dissolved in saline) via the cannula in the right atrium. Blood samples $(0.4 \mathrm{ml})$ were withdrawn 11 and $1 \mathrm{~min}$ before and $2,5,10,15,20,30$ and $45 \mathrm{~min}$ after injection. Immediately after completion of the IVGTT, rats were infused for $24 \mathrm{~h}$ with BrdU (Boehringer Mannheim $\mathrm{GmbH}$, Mannheim, Germany) dissolved in saline (1.2 mg BrdU/h), for visualization of pancreatic cell proliferation. After $24 \mathrm{~h}$ BrdU infusion and 7 days of progesterone treatment, rats were killed by aortic puncture under deep ether anaesthesia and the pancreas was removed, divided into head and tail, subsequently snap-frozen in isopentane and stored at $-70^{\circ} \mathrm{C}$ until sectioning.

\section{Pancreatic cell proliferation}

Cryostat sections $(4 \mu \mathrm{m})$ were immunostained for BrdUpositive cells as previously described (5). In brief, frozen sections were fixed with Carnoy (ethanol, chloroform. glacial acetic acid; $6: 3: 1$ ) and incubated for $60 \mathrm{~min}$ with a monoclonal antibody directed against BrdU (kindly donated by Dr L F M H de Leij, Department of Immunology, University of Groningen). Subsequently, they were incubated for $15 \mathrm{~min}$ with a peroxidaseconjugated rabbit anti-mouse antibody. BrdU-positive cells were stained by the use of 3-amino-9-ethyl-carbazole (AEC). Finally, slides were counterstained with Celestine blue and Mayer's haematoxylin.

Per animal pancreatic cell proliferation was determined in one head and one tail section. Cell proliferation within the pancreatic islets was determined by counting all BrdU-positive and BrdU-negative islet cells from randomly chosen islets; at least 1000 islet cells of each animal were counted. Also, in these pancreatic sections cell proliferation in extra-islet tissue was determined. For this, in each section the total number of BrdUpositive cells in extra-islet tissue of six randomly chosen areas $\left(0.79 \mathrm{~mm}^{2}\right.$ each $)$ was counted.

\section{Cell identification}

In intact female rats, in which the present progesterone treatment has previously been shown to stimulate isletcell proliferation (1), BrdU-positive cells were identified using double-staining for BrdU and insulin, glucagon, cytokeratin 20 (expressed in ductular epithelium) or synaptophysin (expressed in neuro-endocrine cells). After fixation in paraformaldehyde (4\%) and incubation with $20 \mu \mathrm{g} / \mathrm{ml}$ proteinase $\mathrm{K}$ (Boehringer Mannheim) for $30 \mathrm{~min}$, sections were incubated for $60 \mathrm{~min}$ with either a guinea pig polyclonal antibody directed against bovine insulin, a mouse antibody against rat glucagon, a mouse antibody against human cytokeratin 20 (Dako, Glostrup, Denmark), or a mouse antibody against synaptophysin (Dako). Subsequently, they were incubated for $30 \mathrm{~min}$ with either a peroxidase-conjugated rabbit anti-guinea pig antibody (insulin) or a phosphatase-conjugated rabbit anti-mouse antibody (glucagon, cytokeratin 20, synaptophysin). Immunoreactive cells were stained by the use of 3,3'-diaminobenzidine (DAB) (insulin) or Fast Red (Sigma) (glucagon, cytokeratin 20, synaptophysin). This was followed by BrdU staining as above, except for staining with DAB instead of AEC (double-staining with glucagon, cytokeratin 20, synaptophysin). For the insulin/BrdU double-staining a phosphatase-conjugated instead of a peroxidase-conjugated rabbit anti-mouse antibody was used, and sections were subsequently stained with Fast Red instead of AEC. In addition, sections were also doublestained for cytokeratin 20 (using a phosphataseconjugated rabbit anti-mouse antibody, staining with Fast Red) and insulin (using a peroxidase-conjugated rabbit anti-guinea pig antibody, staining with DAB).

Within the islets of the pancreatic sections, the percentage BrdU-positive cells which also stained positive for insulin or glucagon was determined. Islets were defined as cell clusters containing more than two 
adjacent insulin-, glucagon- or synaptophysin-positive cells. Furthermore, in extra-islet tissue of six randomly chosen areas $\left(0.79 \mathrm{~mm}^{2}\right.$ each) the percentage BrdUpositive cells which also stained positive for insulin, glucagon, synaptophysin or cytokeratin 20 was determined. In these areas also the incidence of single insulin and glucagon immunoreactive cells was determined. In the pancreatic sections double-stained for cytokeratin 20 and insulin, the number of cytokeratin 20/insulin double-immunoreactive cells was determined in extra-islet tissue of ten randomly chosen areas (0.79 $\mathrm{mm}^{2}$ each).

\section{Determination of glucose, insulin, progesterone, $20 \alpha$-dihydroprogesterone and E2}

Plasma glucose concentrations were measured in diluted plasma samples by the glucose-oxidase/peroxidase method (GOD-Perid, Boehringer Mannheim).

Plasma insulin concentration was determined by double-antibody RIA using a guinea pig antibody against bovine insulin, a rat standard (batch no. 220891, NOVO Nordisk, Bagsvaerd, Denmark), and a donkey anti-guinea pig antibody coated on cellulose particles (SAC-CEL ASAC 3, Immuno Diagnostics, Boldon, UK). Bovine insulin (NOVO Nordisk) was iodinated at the Isotope Laboratory of the Groningen University Hospital, and used as tracer.

Plasma progesterone, 20 $\alpha$-dihydroprogesterone (20 $\alpha$-hydroxy-4-pregn-3-one $(20 \alpha$-OHP $))$ and E2 levels were determined after 6 days of progesterone treatment by RIA, carried out at the Isotope Laboratory of the Groningen University Hospital (progesterone and E2; Dr J J Pratt) and the Department of Endocrinology and Reproduction of the Erasmus University, Rotterdam (20 $\alpha$-OHP; Dr J Uilenbroek).

\section{Parameters and statistics}

Glucose tolerance during the i.v. glucose load was evaluated using the glucose disappearance constant $\left(\mathrm{K}_{\mathrm{G}}\right)$ calculated as the slope of the least-square regression line relating the natural logarithm of the glucose concentration to time between 5 and $15 \mathrm{~min}$, expressed as $\% / \mathrm{min}(11)$. For the insulin responses to the i.v. glucose load, the areas under the curves (AUC) were calculated from 0 to 15 min after glucose injection. Data are expressed as mean \pm s.E.M. Statistical comparisons were made by a Mann-Whitney U test. A level of random difference of $P<0.05$ was considered significant.

\section{Results}

\section{Plasma concentrations of progesterone, $20 \alpha-O H P$ and $E 2$}

Plasma concentrations of progesterone (Fig. 1a) and 20 $\alpha$ OHP (Fig. 1b) were lower in gonadectomized rats and in male rats when compared with intact female rats not treated with progesterone. In all experimental groups, plasma concentrations of progesterone and $20 \alpha-\mathrm{OHP}$ were increased after 6 days of progesterone treatment.

In non-progesterone treated OVX rats, E2 supplementation increased plasma E2 concentrations $(0.72 \pm 0.12 \mathrm{nmol} / \mathrm{l}$ vs not detected). Progesterone treatment for 6 days did not affect plasma E2 levels in E2-supplemented OVX rats $(0.96 \pm 0.22$ vs $0.72 \pm 0.12 \mathrm{nmol} / \mathrm{l}$, not significant (NS)).

\section{Pancreatic cell proliferation}

Within the pancreatic islets Figure 2a shows that the rate of cell proliferation within the pancreatic islets was identical in all non-progesterone treated rats, male or female, intact or gonadectomized and whether or not supplemented with E2. Progesterone treatment for 7 days increased islet-cell proliferation in intact female and male rats. In gonadectomized rats, however, whether or not supplemented with E2, progesterone treatment did not affect islet-cell proliferation.

Outside the pancreatic islets In female rats, ovariectomy per se increased the rate of cell proliferation in extra-islet pancreatic tissue (Fig. 2b); this increased rate of extra-islet cell proliferation was suppressed by E2 supplementation. In (non-progesterone treated) intact male rats, cell proliferation rates of extra-islet pancreatic tissue were higher than in (non-progesterone treated) female rats; moreover, in contrast to female rats, castration did not affect cell proliferation in extraislet pancreatic tissue in male rats. Furthermore, progesterone treatment for 7 days stimulated cell proliferation of extra-islet pancreatic tissue in both intact female and male rats, but was without effect in any group of gonadectomized rats.

\section{Identification of proliferating cells}

Within the pancreatic islets In intact female rats not treated with progesterone, $79.8 \pm 10.6 \%$ of all BrdUpositive cells within the pancreatic islets contained immunoreactive insulin, while $17.0 \pm 4.4 \%$ of all BrdUpositive cells contained immunoreactive glucagon. After 7 days of progesterone treatment these percentages were $72.9 \pm 3.7$ and $18.6 \pm 1.9 \%$ respectively. The effects of progesterone were not statistically significant.

Outside the pancreatic islets In intact female rats not treated with progesterone, the incidence of insulinimmunoreactive cells in extra-islet pancreatic tissue was $1.6 \pm 0.1$ cells $/ \mathrm{mm}^{2}$, and that of glucagonimmunoreactive cell $2.8 \pm 0.2$ cells $/ \mathrm{mm}^{2}$. In progesterone-treated female rats, the incidence of insulinimmunoreactive cells in extra-islet pancreatic tissue was unaffected $\left(1.3 \pm 0.2\right.$ cells $/ \mathrm{mm}^{2}$, NS), but the incidence of glucagon-immunoreactive cells was diminished 
Figure 1 Plasma concentrations of progesterone (a) and $20 \alpha$-OHP (b) in intact female, OVX, E2supplemented OVX (OVX+E2) and intact and TX male rats after 6 days of treatment with progesterone-containing (solid bars) and empty (open bars) implants. The symbols \# and * denote statistically significant differences $(P<0.05)$ when compared with non-progesterone treated intact female rats, and to the appropriate non-progesterone treated controls respectively. ND, not detected $(<0.5 \mathrm{ng} / \mathrm{ml})$. In each group, $n=5-7$.
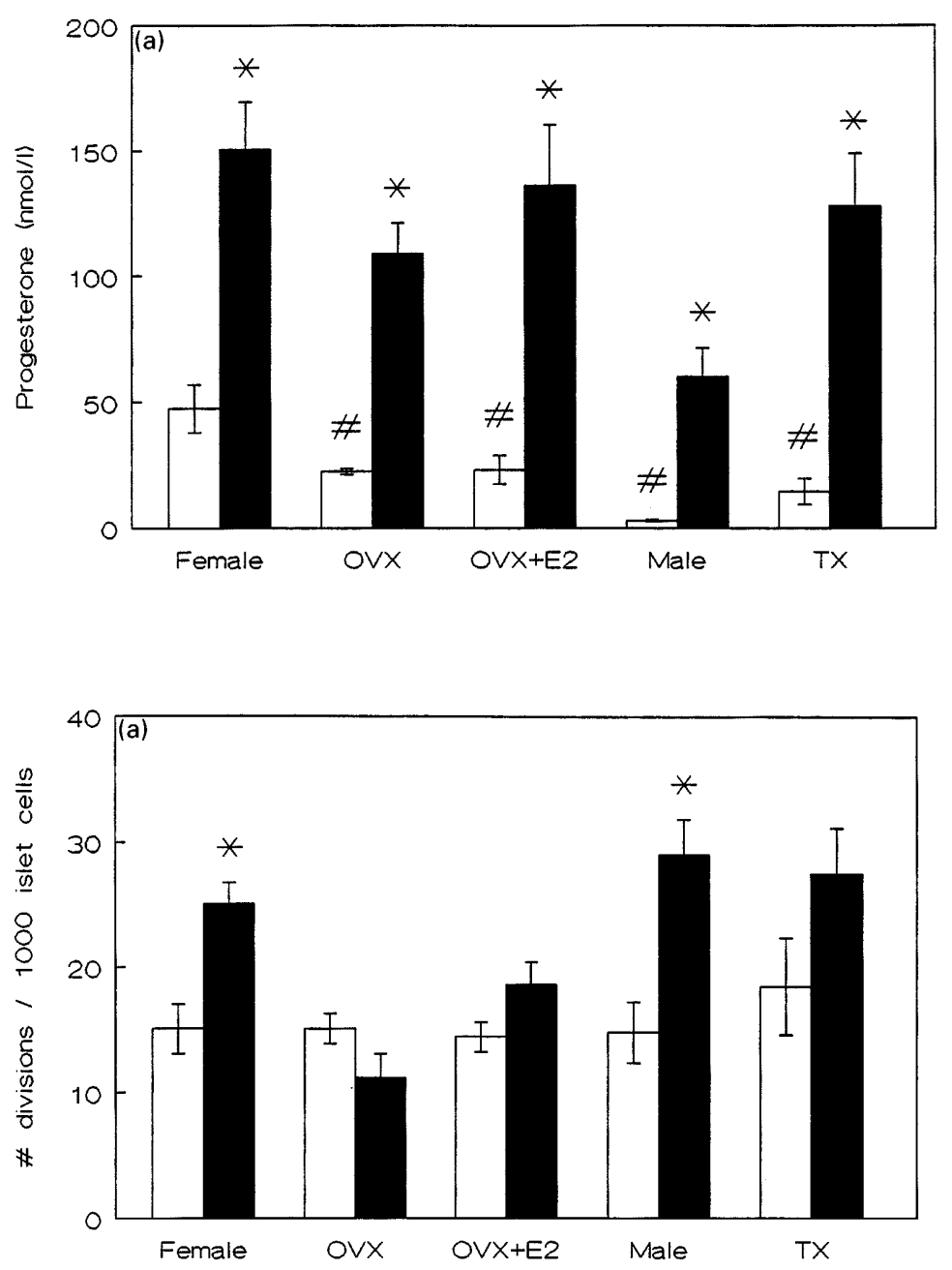

$\left(1.6 \pm 0.2\right.$ cells $\left./ \mathrm{mm}^{2}, P<0.05\right)$ when compared with female rats not treated with progesterone.

Figure 3 shows pancreatic sections, double-stained for BrdU and cytokeratin 20, of intact female rats after 7 days of sham treatment (Fig. 3a) or after 7 days of progesterone treatment (Fig. 3b). In extra-islet pancreatic tissue of intact female rats, progesterone treatment increased the incidence of cytokeratin 20/BrdU doublepositive cells $\left(13.0 \pm 1.1\right.$ vs $1.9 \pm 0.7$ cells $/ \mathrm{mm}^{2}, P<$ 0.05). Also, the number of cytokeratin 20-negative/ BrdU-positive cells increased (35.6 \pm 2.7 vs $5.0 \pm 1.5$ cells $\left./ \mathrm{mm}^{2}, P<0.05\right)$, so that the percentage cytokeratin 20-positive cells within the BrdU-immunoreactive population was similar in progesterone-treated and non-progesterone treated female rats $(26.8 \pm 0.9$ vs $24.2 \pm 6.9 \%$, NS). The number of insulin/BrdU, glucagon/BrdU and synaptophysin/BrdU double-positive cells was very low in non-progesterone treated female rats: only $0.4 \pm 0.2 \%$ of the BrdU-positive cells also stained positive for glucagon, while no BrdU-positive cells were also positive for insulin or synaptophysin. After 6 days of progesterone treatment, $0.4 \pm 0.2 \%$ of the BrdUpositive cells also stained positive for insulin, but in these animals no BrdU-positive cells also stained positive for glucagon or synaptophysin.

Figure 4 shows a pancreatic section of an intact female rat, not treated with progesterone, doublestained for insulin and cytokeratin 20. In intact female rats not treated with progesterone, the incidence of cytokeratin 20/insulin double-immunoreactive cells in pancreatic tissue was $0.18 \pm 0.06$ cells $/ \mathrm{mm}^{2}$. In progesterone-treated female rats, this incidence was $0.31 \pm 0.10$ cells $/ \mathrm{mm}^{2}$ (NS).

\section{IVGTT}

Glucose tolerance Glucose tolerance, calculated as the $\mathrm{K}_{\mathrm{G}}$, was not affected by progesterone treatment in any experimental group: $4.3 \pm 0.2$ vs $4.4 \pm 0.2 \% / \mathrm{min}$ in intact female rats, $3.8 \pm 0.3$ vs $3.8 \pm 0.4 \% / \mathrm{min}$ in OVX rats, $4.4 \pm 0.2$ vs $4.2 \pm 0.1 \% / \mathrm{min}$ in E2-supplemented OVX rats, $4.0 \pm 0.1$ vs $4.3 \pm 0.1 \% / \mathrm{min}$ in intact male 

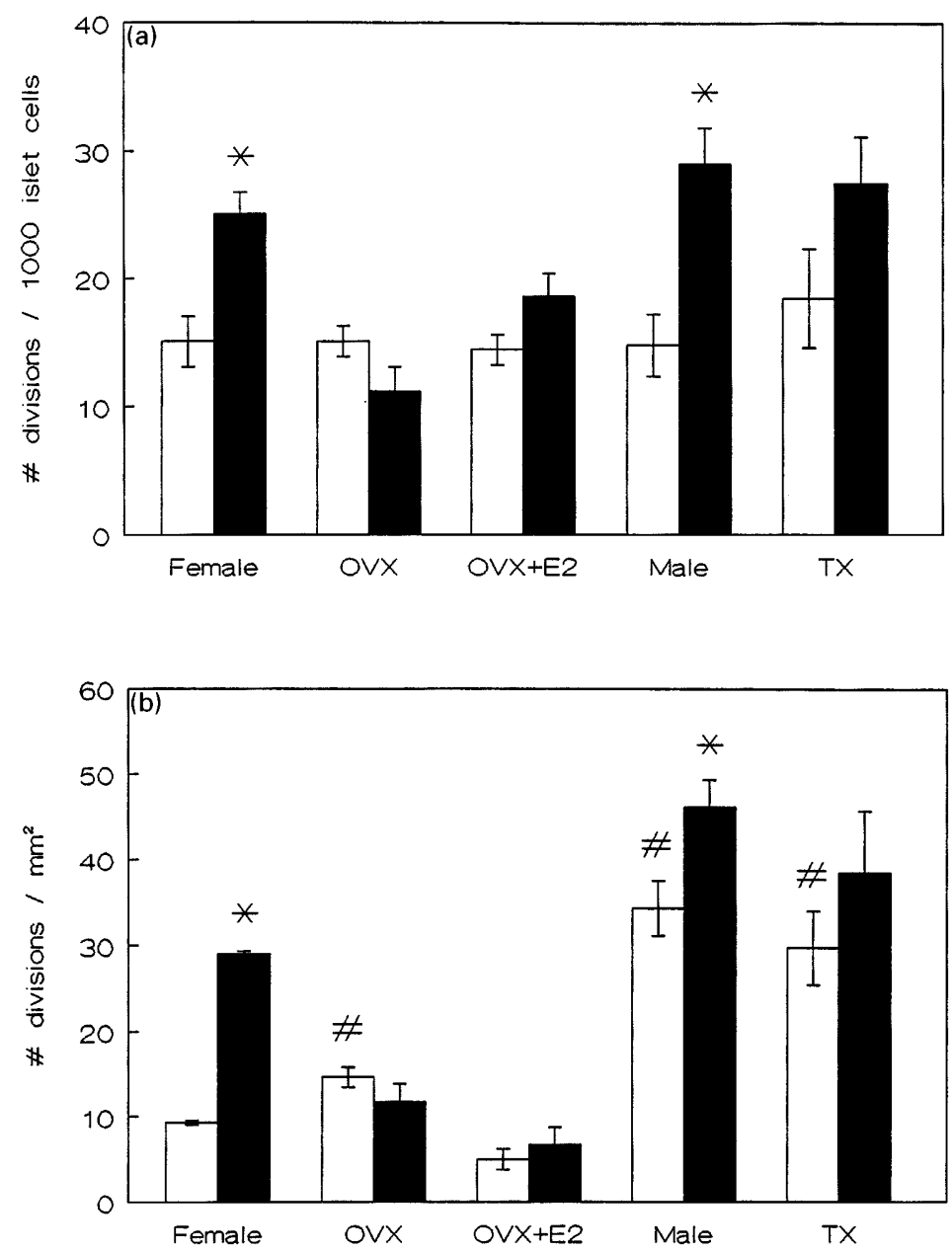

Figure 2 Cell proliferation rates in pancreatic islets (a) and extra-islet pancreatic tissue (b) of intact female, OVX, E2-supplemented OVX (OVX+E2) and intact and TX male rats after 7 days of treatment with progesteronecontaining (solid bars) and empty (open bars) implants. The symbols \# and * denote statistically significant differences $(P<0.05)$ when compared with non-progesterone treated intact female rats, and to the appropriate non-progesterone treated controls respectively. In each group $n=5-7$. rats, and $3.7 \pm 0.2$ vs $3.9 \pm 0.3 \% / \mathrm{min}$ in TX rats (for all groups: NS).

Insulin responses In intact female rats, after 6 days of progesterone treatment, baseline plasma insulin levels were increased when compared with non-progesterone treated female rats $(3.9 \pm 0.5$ vs $2.3 \pm 0.3 \mathrm{ng} / \mathrm{ml}, P<$ 0.05). In all other experimental groups, progesterone treatment did not affect baseline plasma insulin levels.

Progesterone treatment for 6 days did not affect plasma insulin responses to an i.v. glucose challenge, as calculated as AUC, in any experimental group: $79 \pm 19$ vs $54 \pm 5 \mathrm{ng} / \mathrm{ml} \mathrm{min}$ in intact female rats, $69 \pm 20$ vs $74 \pm 16 \mathrm{ng} / \mathrm{ml} \mathrm{min}$ in OVX rats, $94 \pm 6 \mathrm{vs} 80 \pm 14 \mathrm{ng} / \mathrm{ml}$ min in E2-supplemented OVX rats, $61 \pm 15$ vs $71 \pm 12 \mathrm{ng} / \mathrm{ml} \mathrm{min}$ in intact male rats, and $83 \pm 6 \mathrm{vs}$ $66 \pm 8 \mathrm{ng} / \mathrm{ml} \mathrm{min}$ in castrated male rats (for all groups: NS).

\section{Discussion}

Progesterone treatment stimulated islet-cell proliferation in both intact male and female rats, although only female rats possess significant amounts of pancreatic progesterone receptors $(2-4)$. Moreover, the effect of progesterone on islet-cell proliferation was absent in TX male and OVX female rats, suggesting that the gonads play an essential role in the genesis of the proliferative effect of progesterone. Yet, it cannot be excluded that progesterone has an effect also in TX rats, but that this effect is masked by the large variations in cell proliferation rates in both control and progesteronetreated TX rats. In OVX rats, the absence of an effect of progesterone on islet-cell proliferation might be explained by the loss of progesterone binding sites within the pancreatic islets after ovariectomy (3). However, although E2 treatment may prevent the loss of progesterone receptors after ovariectomy (3), it did not prevent the loss of the stimulatory effect of progesterone on islet-cell proliferation. It, therefore, appears that in both male and female rats the effect of progesterone treatment on islet-cell proliferation is not mediated by progesterone receptors within the islets. Rather, the effect of progesterone treatment is indirect and, as the effect disappears after gonadectomy, is mediated by (some) gonadal factor(s). The involvement 

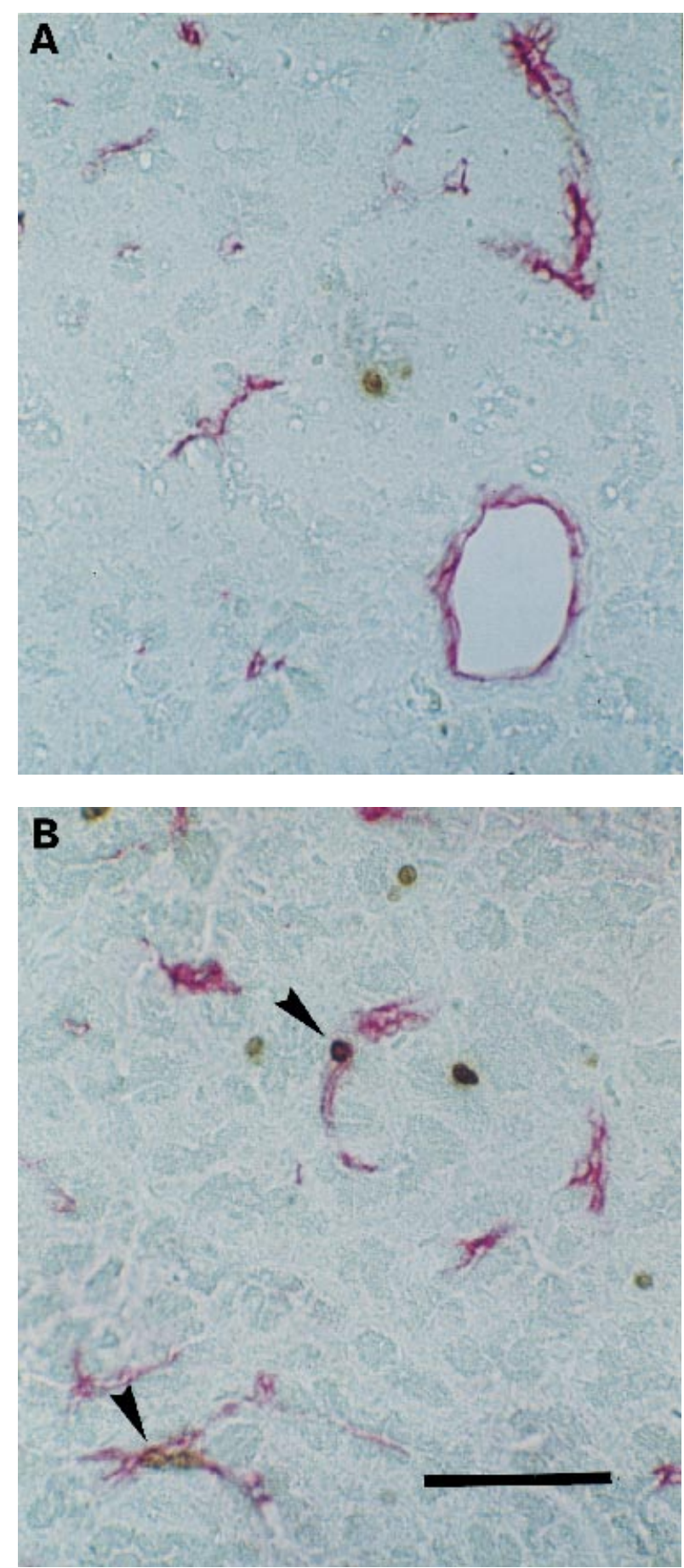

Figure 3 Pancreatic tissue sections of intact female rats which had been treated with either three empty (a) or three progesteronecontaining (b) Silastic implants for 7 days, and infused with BrdU over the last $24 \mathrm{~h}$. The sections have been double-stained for BrdU (brown) and cytokeratin 20 (red). Arrows indicate BrdU and cytokeratin 20 double-positive cells; scale bar represents $50 \mu \mathrm{m}$.

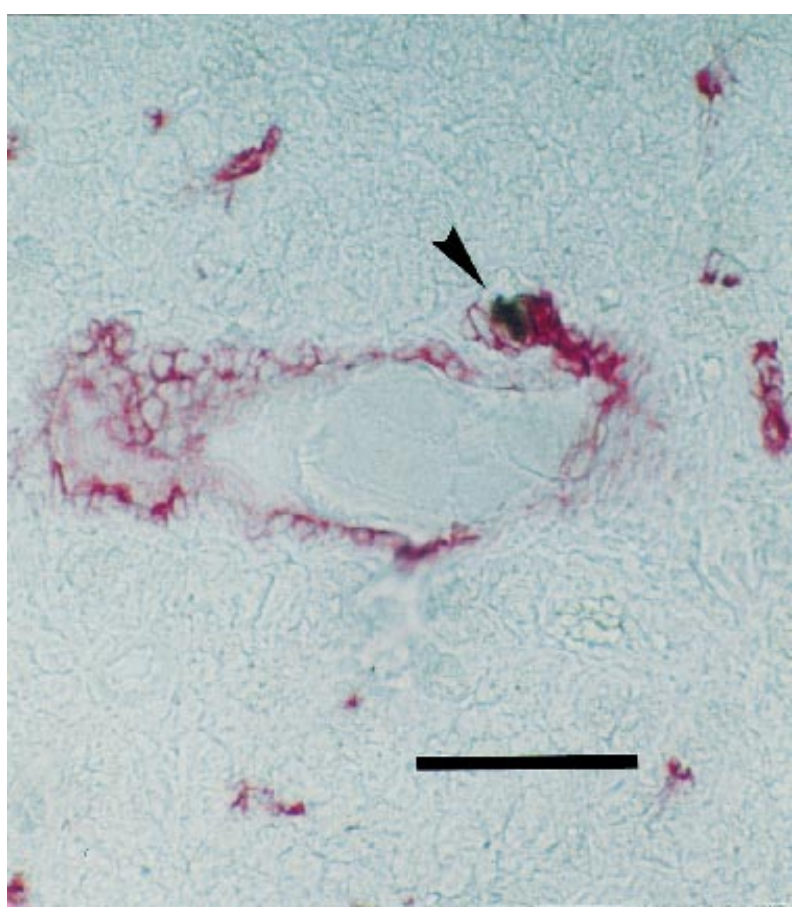

Figure 4 Pancreatic tissue section of an intact female rat, doublestained for insulin (brown) and cytokeratin 20 (red). Arrow indicates insulin and cytokeratin 20 double-positive cell; scale bar represents $50 \mu \mathrm{m}$.

of these gonadal factor(s) might also explain the discrepancy between the stimulation of islet-cell proliferation by progesterone in vivo, as shown in the present study, and the inhibitory effects of progesterone on islet-cell proliferation in vitro (12-14), under which conditions such factors are absent.

Clearly, E2 does not represent the above mentioned gonadal factor, as E2 administration did not restore the proliferative effect of progesterone in OVX rats. Previously, we suggested that increased levels of another ovarian steroid, $20 \alpha$-OHP, which can be synthesized from progesterone by the ovaries (15), might be involved in the stimulation of islet-cell proliferation by progesterone treatment (1). However, the present results show that in the progesterone-treated gonadectomized rats high levels of $20 \alpha$-OHP do not correspond with increased cell proliferation. Next to steroids, the gonads of the male and the female produce and secrete appreciable amounts of all kinds of growth factors, such as activin and inhibin $(16,17)$, members of the transforming growth factor- $\beta$ superfamily of growth factors, which generally inhibit pancreatic cell replication $(18,19)$, and the insulin-like growth factors-I and II (20-22), which are capable of stimulating pancreatic islet-cell proliferation (23). Moreover, in human testis (24) and ovary (25) a growth hormone/placental lactogen variant is produced which also might stimulate cell proliferation in pancreatic tissue (cf. 26, 27). Modulation of the secretion of these growth factors 
may be involved in the stimulation of pancreatic cell proliferation by progesterone treatment.

The present study shows that the effect of progesterone treatment on cell proliferation is not limited to the pancreatic islets (1). Also in extra-islet pancreatic tissue cell proliferation was stimulated after treatment with progesterone. This agrees with the increased pancreatic mass after progesterone treatment, as described previously (28). Perhaps the stimulatory effect of progesterone treatment on cell proliferation within the pancreas should be seen in the light of earlier observations that progesterone is able to stimulate cell proliferation in many other tissues, such as uterus, oviduct and mammary gland (29). Furthermore, the effect of progesterone on pancreatic cell proliferation does not seem to be restricted to a single cell type. Thus, in extra-islet pancreatic tissue, double-immunostaining revealed that there was increased proliferation of ductular (i.e. cytokeratin 20-immunoreactive) cells, although these cells were not preferably stimulated by progesterone, as the relative contribution of ductular epithelium to the total number of cell replications in extra-islet pancreatic tissue did not increase. We did not detect any proliferating synaptophysin-immunoreactive (i.e. neuro-endocrine (6)) cells in non-islet pancreatic tissue. Hence, progesterone treatment stimulated cell proliferation in other cell types present in extra-islet pancreatic tissue, of which by far the most abundant are acinar cells $(30,31)$.

Within the islets themselves, in intact female rats, the ratio of proliferating $\alpha$ and $\beta$ cells remained constant after progesterone treatment, suggesting that progesterone stimulated the proliferation of both cell types to the same extent. Besides replication of existing $\alpha$ and $\beta$ cells, new islet ( $\alpha$ and $\beta$ ) cells can also be formed by differentiation from stem cells present within the ductal epithelium of the adult rat pancreas (32-35). Still, in the present study there were no signs of increased differentiation of ductal cells into endocrine cells. Thus, neither the incidence of single endocrine $(\alpha, \beta$ and synaptophysin-immunoreactive) cells in non-islet pancreatic tissue (cf. 33, 34) nor the occurrence of cytokeratin 20/insulin double-immunoreactive cells $(32,33)$, which may represent a transitional form between ductal and $\beta$ cells $(34,35)$, was increased during progesterone treatment. It should be noted, however, that, unlike Wang et al. (33), we did observe some cytokeratin 20/insulin double-immunoreactive cells in adult control rats. All in all, it appears that progesterone treatment promotes proliferation of already differentiated endocrine cells, rather than the process of differentiation of non-endocrine stem cells to endocrine cells. This situation is similar to the condition of pregnancy, where increased progesterone levels (36) are associated with increased islet-cell proliferation (10, 37-39) and not with islet neogenesis (40).

There does not seem to exist a straightforward relationship between the effects of progesterone treatment on islet-cell proliferation and its effects on the metabolic parameters, food intake and glucose-stimulated insulin secretion. The stimulatory effect of progesterone on pancreatic cell proliferation in intact male and female rats was associated with increased food intake in intact female rats (cf. 1,41 ), but not in intact male rats (data not shown). Similarly, in mid-pregnant rats, progesterone treatment does not affect food intake, but stimulates islet-cell proliferation (1). Hence, although food intake might play an important role in the regulation of isletcell proliferation, at least during pregnancy (42) and in diabetic $d b / d b$ mice (43), hyperphagia does not seem to be the general mechanism underlying the increased islet-cell proliferation following progesterone treatment. Furthermore, progesterone treatment did not affect the insulin responses to glucose in any experimental group. Thus, in intact male and female rats, the stimulatory effect of progesterone treatment on proliferation of pancreatic cells, including $\beta$-cells, appears not to be reflected by an increase in insulin secretion. Therefore, at first sight, the physiological significance of the seemingly unspecific effect of progesterone on pancreatic cell proliferation remains undefined. It is suggested that, in the female, progesterone may prepare the pancreas for increased activity during reproduction by stimulating cell proliferation (10,37-39). For the expression of this effect of progesterone, gonadal factor(s) play(s) an essential role.

\section{Acknowledgements}

We would like to thank Ms G C J van der Schaaf-Verdonk and Ms N Valkhof for their technical assistance, and Dr R S B Liem (Laboratory for Cell Biology and Electron Microscopy, University of Groningen) for performing the microphotography.

\section{References}

1 Nieuwenhuizen AG, Schuiling GA, Hilbrands LG, Bisschop EM \& Koiter TR. Proliferation of pancreatic islet cells in cyclic and pregnant rats after treatment with progesterone. Hormone and Metabolic Research $199830649-655$.

2 Green IC, Howell SL, El Seifi S \& Perrin D. Binding of ${ }^{3} \mathrm{H}-$ progesterone by isolated rat islets of Langerhans. Diabetologia $197815349-355$.

3 El Seifi S, Green IC \& Perrin D. Insulin release and steroidhormone binding in isolated islets of Langerhans in the rat: effects of ovariectomy. Journal of Endocrinology 1981 90 59-67.

4 Singh P, Townsend CM \& Thompson JC. Presence of estradiolbinding proteins in gastrointestinal tract of male rats. Endocrinology $19861191648-1653$.

5 Harms G, Van Goor H, Koudstaal J, De Ley L \& Hardonk MJ. Immunohistochemical demonstration of DNA-incorporated 5bromodeoxyuridine in frozen and plastic embedded sections. Histochemistry 198685 139-143.

6 Redecker P, Jorns A, Jahn R \& Grube D. Synaptophysin immunoreactivity in the mammalian endocrine pancreas. Cell and Tissue Research 1991264 461-467.

7 Bouwens L, Wang RN, De Blay E, Pipeleers D \& Klöppel G. Cytokeratins as markers of ductal cell differentiation and islet neogenesis in the neonatal rat pancreas. Diabetes 199443 1279-1283 
8 Steffens AB. A method for frequent sampling of blood and continuous infusion of fluids in the rat without disturbing the animal. Physiology and Behavior 19694 833-836.

9 Koiter TR, Van der Schaaf GCJ \& Schuiling GA. Effects of luteolysis during late pregnancy on pituitary responsiveness to gonadotrophin-releasing hormone in the rat. Journal of Endocrinology $1991128411-418$.

10 Nieuwenhuizen AG, Schuiling GA, Moes H \& Koiter TR. Role of increased insulin demand in the adaptation of the endocrine pancreas to pregnancy. Acta Physiologica Scandinavica 1997159 303-312.

11 Tokuyama K \& Suzuki M. Intravenous glucose tolerance-test derived glucose effectiveness in endurance-trained rats. Metabolism 199847 190-194.

12 Green IC, El Seifi S, Perrin D \& Howell SL. Cell replication in the islets of Langerhans of adult rats: effects of pregnancy, ovariectomy and treatment with steroid hormones. Journal of Endocrinology 198188 219-224.

13 Nielsen JH, Nielsen V, Pedersen LM \& Deckert T. Effects of pregnancy hormones on pancreatic islets in organ culture. Acta Endocrinologica $1986111336-341$.

14 Nielsen JH. Direct effect of gonadal and contraceptive steroids on insulin release from mouse pancreatic islets in organ culture. Acto Endocrinologica 1984105 245-250.

15 Robertson WR, Frost J, Hoyer PE \& Weinkove C. 20 $\alpha$-Hydroxysteroid dehydrogenase activity in the rat corpus luteum; a quantitative cytochemical study. Journal of Steroid Biochemistry $198217237-243$

16 De Jong FH, Grootenhuis AJ, Klaij IA \& Van Beurden WMO. Inhibin and related proteins: localization, regulation, and effects. In Circulating Regulatory Factors and Neuroendocrine Function, ch 17, pp 271-293. Eds JC Porter \& D Jezová. New York: Plenum Press, 1990.

17 Ackland JF, Schwartz NB, Mayo KE \& Dodson RE. Nonsteroidal signals originating in the gonads. Physiological Reviews 199272 $731-787$.

18 Sjöholm $\AA$ \& Hellerström C. TGF- $\beta$ stimulates insulin secretion and blocks mitogenic response of pancreatic $\beta$-cells to glucose. American Journal of Physiology 1991260 C1046-C1051.

19 Logsdon CD, Keyes L \& Beauchamp RD. Transforming growth factor-beta (TGF-beta 1) inhibits pancreatic acinar cell growth. American Journal of Physiology 1992262 G364-G368.

20 Zhou J, Chin E \& Bondy C. Cellular pattern of insulin-like growth factor-I (IGF-I) and IGF-I receptor gene expression in the developing and mature ovarian follicle. Endocrinology 1991129 3281-3288.

21 Hernandez ER, Roberts CT. Hurwitz A, LeRoith D \& Adashi EY. Rat ovarian insulin-like growth factor II gene expression is thecainterstitial cell-exclusive: hormonal regulation and receptor distribution. Endocrinology 1990127 3249-3251.

22 Murphy LJ, Bell GI \& Friesen HG. Tissue distribution of insulin-like growth factor I and II messenger ribonucleic acid in the adult rat. Endocrinology 1987120 1279-1282.

23 Hill DJ \& Hogg J. Growth factor control of pancreatic B cell hyperplasia. Baillière's Clinical Endocrinology and Metabolism 1991 5 689-698.

24 Untergasser G, Kranewitter W, Schwarzler P, Madersbacher S, Dirnhofer S \& Berger P. Organ-specific expression pattern of the human growth hormone/placental lactogen gene-cluster in the testis. Molecular and Cell Endocrinology 1997130 53-60.

25 Schwarzler P, Untergasser G, Hermann M, Dirnhofer S, Abendstein B, Madersbacher S et al. Selective growth hormone/placental lactogen gene transcription and hormone production in pre- and postmenopausal human ovaries. Journal of Clinical Endocrinology and Metabolism 199782 3337-3341.
26 Nielsen JH. Effects of growth hormone, prolactin, and placental lactogen on insulin content and release, and deoxyribonucleic acid synthesis in cultured pancreatic islets. Endocrinology 1982 110 600-606.

27 Brelje TC, Scharp DW, Lacy PE, Ogren L, Talamantes F, Robertson $\mathrm{M}$ et al. Effect of homologous placental lactogens, prolactins, and growth hormones on islet B-cell division and insulin secretion in rat, mouse, and human islets: implication for placental lactogen regulation of islet function during pregnancy. Endocrinology 1993 $132879-887$.

28 Haist RE. Effects of steroids on the pancreas. Methods in Hormone Research 19654 193-233.

29 Clarke CL \& Sutherland RL. Progestin regulation of cellular proliferation. Endocrine Reviews 199011 266-301.

30 Githens S. The pancreatic duct cell: proliferative capabilities, specific characteristics, metaplasia, isolation and culture. Journal of Pediatric Gastroenterology and Nutrition 19887 486-506.

31 Elsässer HP, Biederbick A \& Kern HF. Growth of rat pancreatic acinar cells quantitated with a monoclonal antibody against the proliferating nuclear antigen. Cell and Tissue Research 1994276 603-609.

32 Bonner-Weir S, Baxter LA, Schuppin GT \& Smith FE. A second pathway for regeneration of adult exocrine and endocrine pancreas; a possible recapitulation of embryonic development. Diabetes 199342 1715-1720.

33 Wang RN, Klöppel G \& Bouwens L. Duct- to islet-cell differentiation and islet growth in the pancreas of duct-ligated adult rats. Diabetologia 199538 1405-1411.

34 Bouwens L \& Klöppel G. Islet cell neogenesis in the pancreas. Virchows Archives 1996427 553-560.

35 Vinik A, Rafaeloff R, Pittenger G, Rosenberg L \& Duguid W. Induction of pancreatic islet neogenesis. Hormone and Metabolic Research 199729 278-293.

36 Sutter-Dub MT, Leclercq R, Felix JM, Jacquot R \& Sutter BCJ. Serum progesterone and immuno-reactive insulin levels in the pregnant rat. Hormone and Metabolic Research 19735 18-21.

37 Green IC, El Seifi S, Perrin D \& Howell SL. Cell replication in the islets of Langerhans of adult rats: effects of pregnancy, ovariectomy and treatment with steroid hormones. Journal of Endocrinology 198188 219-224.

38 Dunger A, Lucke S, Besch W \& Hahn H-J. The rat pancreatic B-cell during pregnancy and after delivery. International Journal of FetoMaternal Medicine 19892 55-61.

39 Parsons JA, Brelje TC \& Sorenson RL. Adaptation of islets of Langerhans to pregnancy: increased islet-cell proliferation and insulin secretion correlates with the onset of placental lactogen secretion. Endocrinology 1992130 1459-1466.

40 Parsons JA, Bartke A \& Sorenson RL. Number and size of islets of Langerhans in pregnant, human growth hormone-expressing transgenic, and pituitary dwarf mice: effect of lactogenic hormones. Endocrinology 1995136 2013-2022.

41 Shirling D, Ashby JP \& Baird JD. Effect of progesterone on lipid metabolism in the intact rat. Journal of Endocrinology 198190 285-294.

42 Nieuwenhuizen AG, Schuiling GA, Seijsener L \& Koiter TR. The role of increased food intake in the adaptation of the endocrine pancreas to pregnancy. Physiology and Behavior (In Press).

43 Chick WL \& Like AA. Effects of diet on pancreatic beta cell replication in mice with hereditary diabetes. American Journal of Physiology $1971221202-208$.

Received 22 June 1998

Accepted 4 December 1998 